\title{
INNOVATION MANAGEMENT IN HOTELS INDUSTRY IN AQABA SPECIAL ECONOMIC ZONE AUTHORITY; HOTEL CLASSIFICATION AND ADMINISTRATION AS A MODERATOR
}

\author{
Omar JAWABREH* \\ The University of Jordan, Faculty of Tourism and Hospitality, Department of Hotel Management, Jordan, e-mail: o.jawabreh@ju.edu.jo
}

\begin{abstract}
Citation: Jawabreh, O. (2020). INNOVATION MANAGEMENT IN HOTELS INDUSTRY IN AQABA SPECIAL ECONOMIC ZONE AUTHORITY; HOTEL CLASSIFICATION AND ADMINISTRATION AS A MODERATOR. GeoJournal of Tourism and Geosites, 32(4), 13621369. https://doi.org/10.30892/gtg.32425-581
\end{abstract}

\begin{abstract}
The Paper investigates innovation management in hotels classified in the Aqaba Special Economic Zone Authority: hotel classification and management as a moderator. In order to arrive for the result in factor analysis we used the SPSS version 20 in analyzing 23 items of the Likert scale, before performing axial component analysis, the data's suitability for factor analys is was evaluated. Through by Rotation Sums of Squared Loadings result; we have four items by rotated component matrix was detected the strong loading axial factors. Creati vity is one of the most common and prevalent terms in management literature nowadays, moreover, it has become one of the foundations of success and competition between organizations in terms of their ability to excel, create and innovate, which grants the necessity of deve loping their concepts and administrative methods to set the scene for workers for creativity, and transfer of accumulated knowledge and options.
\end{abstract}

Key words: Human capital, Integration Capability, Relative advantage, Staff related innovation, Product innovation

\section{INTRODUCTION}

The goals management system focuses on both superiors and subordinates. The system provides managers with information about employees, and the method of their performance periodically and continuously. It also helps subordinates to make decisions correctly through a correct information base, and through the system's focus on individual motivation, this leads to improving the level of performance, and it is measured by linking it to results. Thus, there is an opportunity for creativity and innovation.

The process of creativity and innovation requires senior management to look at the long-term future and to make adequate plans for it based on sound, logical thinking. The long-term view or long-term planning should not be considered a waste of time, as some individuals who tend to practical aspects may think, so they demand daily roles more than the future view.

Since the time the administration takes to think is also a type of giving and investing, may be on a higher and more profitable level, basic steps will arise in the future that secure work, preserve roles, and raise everyone to the best level. In total, it is not a waste of time or energies but rather a deliberate and productive intensification. The challenges that hinder the creativity of workers can also be dealt with through many strategies, including providing support with regard to developing creative ideas, spreading the spirit of taking risks among workers, giving individuals the freedom to express their thoughts and ideas, encouraging constructive competition betwe en individuals and groups, encouraging interaction with others outside the group, encouraging individuals to use creative means to solve the problems facing them, reducing excessive supervision of workers, improving the general environment in organizations and making it more open, exchanging experiences, and accepting other opinions (Griffin and Page, 1996; Qin and Yu, 2015). Tourism and hospitality management innovation studies have been wideranging as researchers have sought to recognize the creative nature ofvarious organizations and business practices, including product, service innovations, prcess innovations, management innovations, management innovations and institutional innovations. Innovation in management is described as the development and introduction of a state-of-theart management method, procedure, structure or technique that is intended to advance organizational objectives.

Creativity in management is related to new ideas in the field of management, product development, Human capital, Integration Capability, Relative advantage, Staff related innovation, Product innovation, and all known functions of management. In short, administrative creativity is: "Every idea, procedure, or product presented by employees, junior or senior, that is characterized by renewal and addition, and brings administrative, economic, or social benefits for the organization, individuals or society". There is a close relationship between innovation and excellence, and there are recent approaches to innovation that are always linked to achieving the system of excellence for business organizations. This can be done by developing the skills of creators to ensure their ability to transform their ideas into innovative projects, as they are pillars of excellence in quality, leadership and performance development. Despite the fertility of the terms defining creativity and innovation, controversy still exists around differences.the objective of the study is to explore a positive relationship between (creativity associated with employees, integration, comparative advantage, product innovation) and innovation management in hotels classified in the Aqaba Special Economic Zone authority.

\section{LITERATURE REVIEW}

The topic of creativity is receiving wide attention these days, especially since modern societies are moving in a steady pace to advance in a very fast and changing world facing many economic, social and scientific problems. The need for creativity has become urgent in various areas of human activity; no matter how small the idea is since it produces distinctive production (Griffin, 1997; Gottfredson and Aspinall, 2005; Rodríguez-Victoria et al., 2017). Creativity is one of the most common and prevalent terms in management literature nowadays, moreover, it has become one of the foundations of success and competition between organizations in terms of their ability to excel, create and innovate, which grants the necessity of developing their concepts and administrative methods to set the scene for workers for creativity, and transfer of accumulated knowledge and options (Ottenbacher and Gnoth, 2005). The need for creativity appears as a result of the conditions imposed by changes in the organization's environment, such as technological changes,

\footnotetext{
* Corresponding author
} 
changing consumer tastes, or the difference between the organization's actual performance and its desired performance, as it tries to bridge or reduce the gap through the creativity provided by workers (Pikkemaat and Peters, 2005). Therefore, organizations must pay attention to the internal business and the way in which they make their employees have a sense of creativity. This requires working to create the appropriate environment for the creativity process. The results of a study conducted by (Hon, 2011) showed that the organization's environment plays an important role in predicting creativity. The culture of novelty and innovation helps in the optimal utilization of material resources by creating a tangible benefit for the employee so that its effects are reflected on the pe rformance of the organization, strengthening the system of governance and good management by giving way to popular participation in decision-making, and reducing the monopoly of a group of senior government employees that may not, necessarily, meet the needs, aspirations and concerns of simple citizens (Parasuraman et al., 1991; Griffin and Page, 1993; Jones, 1996; Laurie et al., 2006; Leiponen, 2006).

Promoting the creativity of those creative employees will make them able to apply ideas effectively, and develop government work to contribute to making their organization the most innovative one in the world, in addition to encouraging them to launch their ideas and discuss them with their colleagues and superiors, with the aim of converting them into distinct projects that contribute to the efforts of improving performance and achieving the happiness of dealers. In addition to preparing plans for innovation and excellence based on future scenarios is important to read the variations in a scientific way, and designing integrated systems to foresee the future.

An analysis of the internal and external environment and identifying available opportunities will undoubtedly enhance the trend towards a culture of innovation in planning, following up on business, and developing an effective dynamic system to achieve government excellence as a result of the creative coordination, supporting the quality of work life QWL, and values. The study of the characteristics of the innovative personality and the focus on the importance of innovation lead to achieving administrative creativity. The perception of creative problem-solving skills leads to turning creative ideas into organizational plans, the exclusion of traditional methods for solving coordination problems, figuring up proactive solutions for challenges, and using innovative tools.

\section{Creativity associated with employees}

Field studies have shown that there is a relationship between administrative communication and creativity in the different types of organizations dealt with in the studies (García-Morales et al., 2011). It also demonstrated that creative organizations have shown great interest in the administrative communication channels that lead to the creativity of their workers.

In theory, one can say that administrative communication is one of the factors that lead to creativity in the organization, as communication is a means for exchanging ideas, and contributes to finding a common understanding among the members of the organization for their tasks and functions. These results in the coherence of organizational elements let to a commen of the nature of the goals to be achieved (Jahmani et al., 2020). One of the things that must be focused on in organizations is Rewards and Incentives: which stimulate creativity. These are supported by developing a rewards system that fits creativity, and linking the rewards to the creativity systems. Creativity is giving recognition, appreciation and conducting good performance. From the latter developed the so-called "Reward Power" which is one of the sources of organizational strength that has an important role in encouraging the creativity process of individuals within the organization (Jawabreh et al., 2020b; Masadeh et al., 2018).

\section{Integration}

The success of some organizations at present times not only depends on the efforts of their corporate boards, but also requires the efforts and support of their employees. Workers in organizations need support from their managers at work, nevertheless, these managers also need urgent ideas, skills and opinions of their employees regarding the issues and problems of the organization so that they can take the right decisions at the right time and before these problems worsen and constitute an impediment in the continuation of these organizations towards developing and growing for longer periods, therefore human resources, or the so-called intellectual capital, are among the most important resources they possess, and an important asset of theirs (Montoya-Weissand and Calantone, 1994; Pfeffer, 1994; Johne and Storey, 1998; Hartline et al., 2000; Mahdav and Pirzas, 2017). The importance of enabling workers to participate in decision-making with managers is evident in the subordinates' sense of their importance, role and value, which raises their morale and makes them more giving, as it works on the optimal exploitation of the human potential available within the facility (Cavagnolli, 2011). A study (Bock et al., 2005) demonstrated that employees often refuse to share their knowledge because they feel uncomfortable doing so, because this may reduce their chances of being promoted or it may be an unpaid effort.

\section{Innovation Management}

Soosay and Hyland, 2004 showed that innovation is an important factor in maintaining the organization's competition in the long run, since organizations that compete in dynamic markets with fast mobile technologies must meet the risk of competitors overpowering them, and this can only be achieved through innovation. Innovation is a key to business prosperity, especially after the constant change in the state of knowledge, technologies and consumer demand. The weakness of the innovation process in developing countries as (Awadi, 2015) sees it is due to weak management of innovation and lack of optimal investment for developing countries' organizations in their human and intellectual capital, which made them unable to create, innovate and form added value, which is the opposite of institutions in developed countries whose human resources are a source of creativity and an essential and effective element in creating added value and achieving and maintaining competitive advantage. Administrative innovation relates to the social system of the organization (Rifai, 2012). The social system of an organization refers to everything related to the relationships between individuals who interact together to achieve a specific goal. Administrative innovation includes rules, roles, procedures, structures related to the process of communication, exchange between individuals, and the environment. Therefore, the importance of innovation stems from being run by successful administrations according to (Van and Thaens, 2008).

\section{Comparative advantage}

Due to the increase in the number of hotels in Aqaba and the increase in the intensity of competition between these hotels, hotels seek to find methods that help them develop their performance from inside or outside. Therefore, in order for hotels to provide what is better, they must pay attention to internal marketing towards their employees, as internal marketing has been defined as internally connected marketing and works towards employees within the organization as it is considered one of the necessary requirements for the success of the organization's work (Wang et al., 2018). It turned out that among the modern entrances, service organizations and hotel organizations have become dependent on internal marketing in particular, and if properly implemented, it becomes a basic tool that enables hotels to achieve the market goals they want to reach (Sethi, 2000; Selden and MacMillan, 2006; Lee and Jang, 2016). Creativity in management is related to new ideas in the field of management, product development, leadership of work teams, improvement of services to clients, and all known 
functions of management. In short, administrative creativity is: "Every idea, procedure, or product presented by employees, junior or senior, that is characterized by renewal and addition, and brings administrative, economic, or social benefits for the organization, individuals or society.

\section{Product development}

Product innovation as viewed by (Kotler et al., 2002), as providing any good, service, or idea that someone views as a new and unfamiliar thing, the new product is anything that can be interpreted, added, improved, or developed on product specifications and characteristics, whether the physical material, or the services accompanying it. Product innovation leads to satisfying the needs or desires of current or prospective consumers in the targeted market sectors since this product is new to the organization or the market or both of them (Al-Sumaidaie and Youssef, 2014). Developing new products or services continuously is an essential activity for organizations wishing to face competition (Ciappei and Simoni, 2005). In light of the intense competition (Cooper, 1999) believes that organizations have options; either they work to develop their products and services, or exit the market after sometime. The process of providing new goods and services to organizations according to (Kotler and Armstrong, 2002), enables organizations to effectively meet the needs and desires of customers, and it is a basis for the development, progress, and success of contemporary organizations (Jawabreh et al., 2020a).

\section{MATERIAL AND METHODS}

The current study took place in Aqaba Special Economic Zone Authority; Aqaba covers the total Jordanian coastline (27 km), and hosts the 12 seaports of Jordan, an international airport and the historical city of Aqaba. The city is known for its beauty and rich culture and heritage. The ASEZ is regulated by the Aqaba Special Economic Zone Authority (ASEZA), which is mandated with all the authorities to manage, regulate and operate as a municipality for the ASEZ. It also aims to develop the ASEZ as the epicenter of best practices in Jordan (Jawabreh, 2017). All hotel classifications were included in the sample frame as the results and information from the current study would be more generalizable and give a view of the Aqaba hospitality industry as a whole. Because of the time and financial constraints of the research, not all hotels could be approached. A sample was drawn from the population via a systematic random sampling technique.

Hotels were contacted by telephone to identify potential projects for study and the person best able to respond to the questions. The aims of the research were explained to staff that were also promised a summary of the results from the survey in return for completing the questionnaire. When staff confirmed that they had developed new hospitality services during the past 3 years and agreed to participate in the study, a copy of the questionnaire was mailed to potential respondents. The questionnaire sought information of the following issues: (a) the factors influencing Management Innovation, (b) Human capital, (c) Integration Capability, (d) Relative advantage (e) Staff related innovation, and (f) Product innovation. Background information on the respondent and hospitality organizations. Following a pretest with hospitality Staff, the rating scale changed from a 7- to a 5-point scale, because Staff had trouble discriminating and found it easier to respond to a 5-point scale. Furthermore, the pretest indicated that hospitality Staff sometimes had problems answering the Likert-type scales. Exploratory factor analysis and Cronbach's alpha tests were then used to assess the convergent and discriminant validity and internal reliability of the scales. The first version of the questionnaire was prepared in Arabic and then translated into English. The appropriateness of the questionnaire was confirmed through the evaluation by academics knowledgeable about and in pretests with hospitality staff in Jordan. Questionnaires were sent out to 150 hospitality staff in Aqaba.

\section{Study hypotheses}

1- The creativity associated with employees positively affects the management of innovation in hotels classified in the Aqaba Special Economic Zone authority

2- Integration positively affects innovation management in hotels classified in the Aqaba Special Economic Zone authority

3- The comparative advantage positively affects innovation management in hotels classified in the Aqaba Special Economic Zone authority

4- Product innovation affects positively the innovation management of hotels classified in the Aqaba Special Economic Zone authority

5- Hotel classification and management will lead to a positive relationship between (creativity associated with employees, integration, comparative advantage, product innovation) and innovation management in hotels classified in the Aqaba Special Economic Zone authority

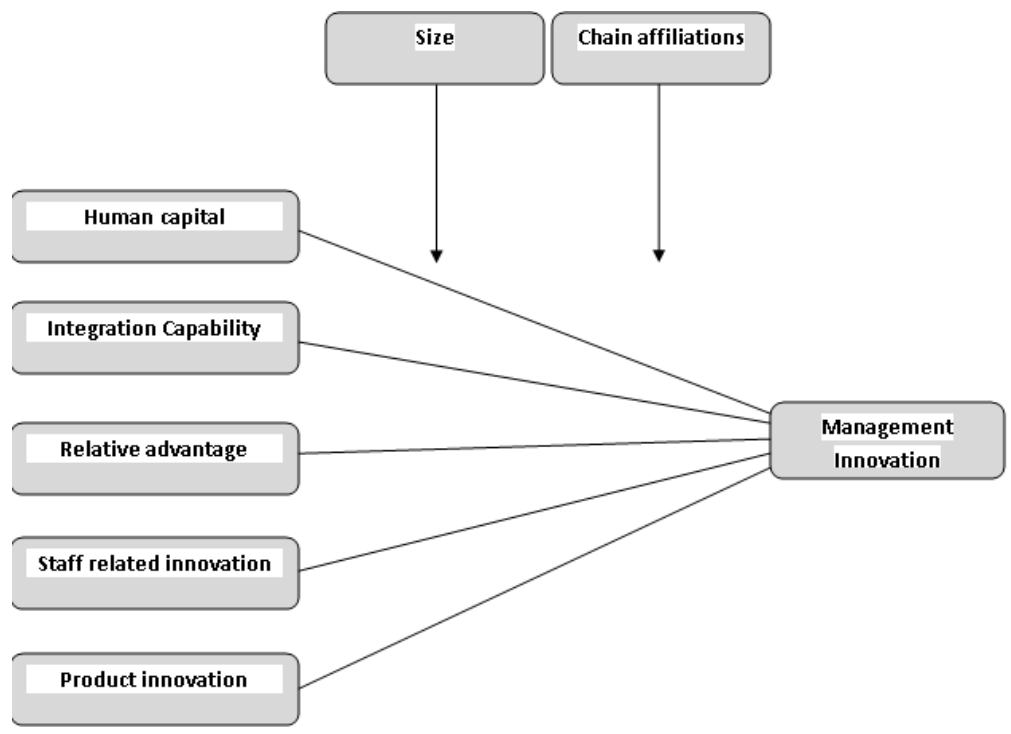

Figur 1. The research model

\section{Factor analysis}

In order to arrive for the result in factor analysis we used the SPSS version 20 in analyzing 23 items of the Likert scale, before performing axial component analysis, the data's suitability for factor analysis was evaluated. In the correlation matrix we detected the presence of many 
coefficients of 0.3 and above. The Kaiser-Meyer-Oklin value was 0.922, and the Bartlett's Test of Sphericity reached statistical significance, supporting the factorability of the correlation matrix. Axial components analysis with Varimax rotation was used. Through by Rotation Sums of Squared Loadings result, we have four items by rotated component matrix was detected the strong loading axial factors.

\section{Reliability}

To make sure the reliability of the tool we ar using the Cronbach's Alpha equation to sample the original study, so as to know the stability of the internal consistency for each field of study, Table 1 explains that:

Table 1. Results for person correlation between paragraph and items, and Cronbach's Alpha

\begin{tabular}{|c|c|c|}
\hline Paragraph & Factor loading & Cronbach's Alpha \\
\hline 1 & 0.543 & \multirow{7}{*}{0.72} \\
\hline 2 & 0.851 & \\
\hline 3 & 0.329 & \\
\hline 4 & 0.392 & \\
\hline 5 & 0.529 & \\
\hline 6 & 0.870 & \\
\hline 7 & 0.809 & \\
\hline 8 & 0.592 & \multirow{5}{*}{0.74} \\
\hline 9 & 0.597 & \\
\hline 10 & 0.552 & \\
\hline 11 & 0.802 & \\
\hline 12 & 0.820 & \\
\hline 13 & 0.774 & \multirow{4}{*}{0.78} \\
\hline 14 & 0.857 & \\
\hline 15 & 0.861 & \\
\hline 16 & 0.828 & \\
\hline 17 & 0.771 & \multirow{3}{*}{0.70} \\
\hline 18 & 0.855 & \\
\hline 19 & 0.648 & \\
\hline 20 & 0.662 & \multirow{4}{*}{0.72} \\
\hline 21 & 0.885 & \\
\hline 22 & 0.780 & \\
\hline 23 & 0.461 & \\
\hline
\end{tabular}

The first hypothesis: creativity related to employees positively affects innovation management in hotels classified in the Aqaba Special Economic Zone Authority. To confirm this hypothesis, a simple regression analysis test was performed, as shown in the following table * Statistically significant at the level of statistical significance $(\alpha \leq 0.05)$

Table 2.The results for simple linear regression

\begin{tabular}{|c|c|c|c|c|c|c|c|c|c|}
\hline \multirow{2}{*}{$\mathbf{R}$} & \multirow{2}{*}{ R Square } & \multirow{2}{*}{ Adjusted R Square } & \multirow{2}{*}{$\mathbf{F}$} & \multirow{2}{*}{ Sig* } & \multicolumn{4}{|c|}{ Regression coefficients } \\
\cline { 5 - 9 } & & & & \multicolumn{2}{|c|}{ Domain } & $\boldsymbol{\beta}$ & Std. Error & T & Sig* \\
\hline 0.635 & 0.403 & 0.398 & 79.69 & $\mathbf{0 . 0 0} *$ & creativity associated with employees & 0.635 & 0.118 & 8.92 & $.000 *$ \\
\hline
\end{tabular}

We note from the Table 2 that there is a positive correlation for creativity related to employees with the innovation management in hotels, as the correlation coefficient reached (0.635). Also, the results of the regression analysis showed a statistically significant effect of creativity related to workers, where the value of $(\mathrm{P})$ was (79.693), in terms of A statistic less than $(0.00)$, and this is confirmed by the (T) test. The results also showed that the explained variance reached (0.398), meaning that the percentage of the creativity effect related to the two workers was $(39.8 \%)$, and the beta value was $(0.635)$. This means that there is a positive impact on the creativity associated with the employees on innovation management in the hotels classified in the Aqaba Special Economic Zone Authority. The challenges that hinder the creativity of workers can also be dealt with through many strategies, including providing support with regard to developing creative ideas, spreading the spirit of taking risks among workers, giving individuals the freedom to express their thoughts and ideas, encouraging constructive competition between individuals and groups, encouraging interaction with others outside the group, encouraging individuals to use creative means to solve the problems facing them, reducing excessive supervision of workers, improving the general env ironment in organizations and making it more open, exchanging experiences, and accepting other opinions (Zhou et al., 2018).

The second hypothesis: Integration positively affects innovation management in hotels classified in the Aqaba Special Economic Zone Authority. To confirm this hypothesis, a simple regression analysis test was performed, as shown in the following table:

Table. 3. The results for simple linear regression

\begin{tabular}{|c|c|c|c|c|c|c|c|c|c|}
\hline \multirow{2}{*}{$\mathbf{R}$} & \multirow{2}{*}{ R Square } & \multirow{2}{*}{ Adjusted R Square } & \multirow{2}{*}{$\mathbf{F}$} & \multirow{2}{*}{ Sig* } & \multicolumn{5}{|c|}{ Regression coefficients } \\
\hline & & & & & Domain & $\beta$ & Std. Error & $\mathbf{T}$ & Sig* \\
\hline .4380 & .192 & .185 & 28.079 & $0.00 *$ & Integration & .4380 & .1010 & 5.299 & $.000 *$ \\
\hline
\end{tabular}

* Statistically significant at the level of statistical significance $(\alpha \leq 0.05)$

We note from the Table 3 that there is a positive correlation for integration with the innovation management in hotels, where the correlation coefficient reached (0.438). Also, the results of the regression analysis showed a statistically significant effect of the integration, where the value of (P) was (28.079), in statistical terms less than (0.00), and this was confirmed by (T) test. The results also showed that the explained variance reached (0.185), meaning that the percentage of the integration effect amounted to $(18.5 \%)$, and the beta value was $(0.438)$. This means that there is a positive impact of integration on the management of innovation in the hotels classified in the Aqaba Special Economic Zone Authority. The importance of enabling workers to participate in decision-making with managers is evident in the subordinates' sense of their importance, 
role and value, which raises their morale and makes them more giving, as it works on the optimal exploitation of the human potential available within the facility (Al-Sabab, 2017). A study (Bock et al., 2005) demonstrated that employees often refuse to share their knowledge because they feel uncomfortable doing so, because this may reduce their chances of being promoted or it may be an unpaid effort.

The third hypothesis: The comparative advantage affects positively the innovation management in the hotels classified in the Aqaba Special Economic Zone Authority. To confirm this hypothesis, a simple regression analysis test was performed, as shown in the following table.

Table 4. The results for simple linear regression

\begin{tabular}{|c|c|c|c|c|c|c|c|c|c|}
\hline \multirow{2}{*}{$\mathbf{R}$} & \multirow{2}{*}{ R Square } & \multirow{2}{*}{ Adjusted R Square } & \multirow{2}{*}{$\mathbf{F}$} & \multirow{2}{*}{ Sig* } & \multicolumn{5}{|c|}{ Regression coefficients } \\
\hline & & & & & Domain & $\beta$ & Std. Error & $\mathbf{T}$ & Sig* \\
\hline .336 & .113 & .105 & 15.027 & $0.00 *$ & comparative advantage & 336.0 & .1010 & 876.3 & $.000 *$ \\
\hline
\end{tabular}

* Statistically significant at the level of statistical significance $(\alpha \leq 0.05)$

From the Table 4, there is a positive correlation for the comparative advantage with the innovation management in hotels, where the correlation coefficient reached (0.336). Also, the results of the regression analysis showed a statistically significant effect of the comparative advantage, where the value of $(\mathrm{P})$ was $(15.027)$, in statistical terms less than $(0.00)$, and this was confirmed by (T) test. The results also showed that the explained variance reached (0.105), meaning that the percentage of the effect of comparative advantages reached (10.5\%), and the value of beta was (0.336). This means that there is a positive impact of the comparative advantage on innovation management in the hotels classified in the Aqaba Special Economic Zone Authority. In order for hotels to achieve excellence, diligent work must be done on developing its services and focusing on external factors; such as the advertisement provided by the hotel service provider, the level of the prices announced, the experiences of friends, acquaintances, internal influences which include decoration, the surrounding atmosphere, service methods, the types of services used in the guest rooms, reception halls, banquet halls, parties, conferences and service technologies to draw a positive picture in clients' minds and achieve satisfaction with those services (Wijethilake et al., 2018 ). This was confirmed by a study of (Guttentag and Smith, 2017) to pay attention to enhance the guest's mental image through the external and internal influences of hotel organizations, work to add value and diversity of hotel services and their integration to achieve guest loyalty. Chandrakumara and Sparrow, 2004 asserts that hotels that want to achieve an advantage over their competitors should design special programs to develop the quality of hotel services so that the hotel management can have an impact on achieving customer satisfaction, achieve a market share for hotels, work on reducing operating costs, and improve the reputation of hotels amongst their customers. Harrington, 2004; Ofondu, 2018; Zubeltu-Jaka et al., 2018 believe that the hotel organization is forced to keep up with its marketing environment by activating the tourism marketing information system to improve the quality of its services and so that it can locate more and stand in the face of various competitive forces. McDonough, 2000; Karniouchina et al., 2006 showed that the developments in the field of communications and information technology led to creating innovations in the process of providing the service through the use of modern technologies, among these innovations are the design of some rooms in an electronic way so that in the case of a visitor feeling sleepy, the room curtains, TV and lighting will close automatically. The study conducted by (Dzhandzhugazova et al., 2016) showed that the re-engineering of operations affects positively in achieving the sustainable competitive advantage of hotels, which would meet the needs and requirements of employees and guests.

The fourth hypothesis: product innovation positively affects innovation management in hotels classified in the Aqaba Special Economic Zone Authority. To confirm this hypothesis, a simple regression analysis test was performed, as shown in the following table:

Table 5. The results for simple linear regression

\begin{tabular}{|c|c|c|c|c|c|c|c|c|c|}
\hline \multirow{2}{*}{$\mathbf{R}$} & \multirow{2}{*}{ R Square } & \multirow{2}{*}{ Adjusted R Square } & \multirow{2}{*}{$\mathbf{F}$} & \multirow{2}{*}{ Sig* } & \multicolumn{5}{|c|}{ Regression coefficients } \\
\hline & & & & & Domain & $\beta$ & Std. Error & $\mathbf{T}$ & Sig* \\
\hline .292 & .085 & .077 & 10.981 & $0.00 *$ & product innovation & 0.292 & 0.103 & 3.314 & $.000 *$ \\
\hline
\end{tabular}

* Statistically significant at the level of statistical significance $(\alpha \leq 0.05)$

From the previous Table 5, there is a positive correlation for product innovation with the innovation management in hotels, where the correlation coefficient was (0.292). Also, the results of the regression analysis showed a statistically significant effect of product innovation, where the value of $(\mathrm{P})$ was $(10.981)$, in statistical terms less than $(0.00)$, and this was confirmed by $(\mathrm{T})$ test. The results also showed that the explained variance reached (0.077), meaning that the effect of product innovation was (7.7\%), and the value of beta was $(0.292)$. This means that there is a positive impact of product innovation on innovation management in classified hotels in the Aqaba Special Economic Zone Authority. With regard to hotels (Laugen et al., 2005) affirmed that there is a strong relationship between the processes of: product innovation, progress, success, and the achievement of a market share for hotels that are interested in improving and providing what is new to customers. Moreover, the success of a hotel depends not only on providing funds, but also on the work and role of the administration, its personnel searched for new services and products. This is the secret of the success of hotels that depends providing high-quality products and services (Song and Parry, 1997; Ottenbacher et al., 2005; Shin et al., 2019). The quality of services and products plays a critical role in the success of enterprises in a competitive environment, as it is the key to accessing markets and attracting customers.

Through improving quality and achieving customer expectations, organizations will be able to reach their goal and determine the price for which they are profitable on the one hand, and which satisfies the customer on the other hand. Most organizations, today, focus on shortening the time required to fulfill customers' requests, so that they can meet the needs that are related to providing the product or service on the set place and time to achieve their satisfaction and gain a new competitive advantage without compromising quality, (Hussein, 2010). It was found, according to a study by (Hashem, 2014), that the Research and Development Department has an effective role in creating new products to achieve a competitive advantage for organizations. Organization in a hotel establishment includes: following the Objective Management System, organizational development methods, and working on managing projects in a flexible manner, in addition to providing a department for quality and quality control. This leads us to talk about the strategy of organizational creativity in order. The fifth hypothesis: the classification of the hotel and management will lead to a positive relationship between (creativity related to workers, integration, comparative advantage, product innovation) and between innovation management in hotels classified in the Aqaba Special Economic Zone Authority. To ensure the validity of this hypothesis, multiple linear regression test was applied. Tables 6 demonstrate this: 
Table 6. The result for R Square Change

\begin{tabular}{|c|c|c|c|c|c|c|c|c|}
\hline & & & & \multicolumn{5}{|c|}{ Change Statistics } \\
\hline $\mathbf{R}$ & R Square & Adjusted R Square & Std. Error of the Estimate & R Square Change & F Change & df1 & df2 & Sig. F Change \\
\hline 0.680 & 0.463 & 0.429 & 0.47455 & 0.463 & 13.794 & 7 & 112 & $0.000 *$ \\
\hline
\end{tabular}

* Statistically significant at the level of statistical significance $(\alpha \leq 0.05)$

Table 7. The results for multiple regressions

\begin{tabular}{|c|c|c|c|c|c|c|c|}
\hline \multirow[t]{2}{*}{$\mathbf{F}$} & \multirow[t]{2}{*}{ Df } & \multirow[t]{2}{*}{ Sig* } & \multicolumn{5}{|c|}{ Regression coefficients } \\
\hline & & & Domain & $\beta$ & Std. Error & $\mathbf{T}$ & Sig* \\
\hline \multirow[t]{7}{*}{17.794} & \multirow[t]{7}{*}{183} & \multirow[t]{7}{*}{$0.00 *$} & Chain affiliations & 0.174 & 0.139 & 1.810 & 0.073 \\
\hline & & & Size & -0.012 & 0.087 & -0.131 & 0.896 \\
\hline & & & Human capital & -0.261 & 0.077 & -2.988 & $0.003 *$ \\
\hline & & & Staff related innovation & 0.599 & 0.161 & 6.208 & $0.000 *$ \\
\hline & & & Integration Capability & 0.029 & 0.135 & 0.260 & 0.795 \\
\hline & & & Relative advantage & 0.143 & 0.098 & 1.708 & 0.090 \\
\hline & & & Product innovation & -0.016 & 0.096 & -0.191 & 0.849 \\
\hline
\end{tabular}

* Statistically significant at the level of statistical significance $(\alpha \leq 0.05)$

We note from the previous table that the value of the correlation coefficient amounted to (0.647), that the value of the coefficient of determination $(2 \mathrm{R})$ has $(0.419)$, and that the value of the modified coefficient of determination (Adjusted R2) (0.399) indicat es that the independent variables (creativity related to workers, integration, comparative advantage, and product innovation) were able to explain $(39.9 \%)$ of the changes occurring in the dependent variable, and upon entering the variables (hotel classification, hotel size, and hotel management) these variables were able to change the correlation coefficient to (0.463) and this indicates an increase.

The relationship between the independent variables (creativity related to two factors, complementarity, comparative advantage, and product innovation) and the dependent variable.

\section{CONCLUSION}

Most organizations, today, focus on shortening the time required to fulfil customers' requests, so that they can meet the needs that are related to providing the product or service on the set place and time to achieve their satisfaction and gain a new competitive advantage without compromising quality (Hussein, 2010). It was found, according to a study by (Farah and Qanur, 2017), that the Research and Development Department has an effective role in creating new products to achieve a competitive advantage for organizations.

The results of the regression analysis showed a statistically significant effect of product innovation, where the value of (P) was (10.981), in statistical terms less than (0.00), and this was confirmed by $(\mathrm{T})$ test. The results also showed that the explained variance reached $(0.077)$, meaning that the effect of product innovation was (7.7\%), and the value of beta was (0.292). This means that there is a positive impact of product innovation on innovation management in classified hotels in the Aqaba Special Economic Zone Authority.

With regard to hotels, (Laugen et al., 2005) affirmed that there is a strong relationship between the processes of: product innovation, progress, success, and the achievement of a market share for hotels that are interested in improving and providing what is new to customers. Moreover, the success of a hotel depends not only on providing funds, but also on the work and role of the adminis tration, its personnel searched for new services and products. This is the secret of the success of hotels that depend on providing high-quality products and services (Ottenbacher et al., 2005; Al Shaire, 2014). The quality of services and products plays a critical role in the success of enterprises in a competitive environment, as it is the key to accessing markets and attracting customers.

Through improving quality and achieving customer expectations, organizations will be able to reach their goal and determine the price for which they are profitable on the one hand, and which satisfies the customer on the other hand. Most organizations, today, focus on shortening the time required to fulfill customers' requests, so that they can meet the needs that are related to providing the product or service on the set place and time to achieve their satisfaction and gain a new competitive advantage without compromising quality, Grissemann et al., 2013). It was found, according to a study by (Hashem, 2014), that the Research and Development Department has an effective role in creating new products to achieve a competitive advantage for organizations.

The value of the coefficient of determination (2R) has (0.419), and that the value of the modified coefficient of determination (Adjusted R2) (0.399) indicates that the independent variables (creativity related to workers, integration, comparative advantage, and product innovation) were able to explain (39.9\%) of the changes occurring in the dependent variable, and upon entering the variables (hotel classification, hotel size, and hotel management) these variables were able to change the correlation coefficient to (0.463) and this indicates an increase. The relationship between the independent variables (creativity related to two factors, complementarity, comparative advantage, and product innovation) and the dependent variable. The results of the regression analysis showed a statistically significant effect of creativity related to workers, where the value of (P) was (79.693), in terms of A statistic less than (0.00), and this is confirmed by the $(\mathrm{T})$ test. The results also showed that the explained variance reached $(0.398)$, meaning that the percentage of the crea tivity effect related to the two workers was $(39.8 \%)$, and the beta value was $(0.635)$. This means that there is a positive impact on the creativity associated with the employees on innovation management in the hotels classified in the Aqaba Special Economic Zone Authority. The challenges that hinder the creativity of workers can also be dealt with through many strategies, including providing support with regard to developing creative ideas, spreading the spirit of taking risks among workers, giving individuals the freedom to express their thoughts and ideas, encouraging constructive competition between individuals and groups, encouraging interaction with others outside the group, encouraging individuals to use creative means to solve the problems facing them, reducing excessive supervision of workers, improving the general environment in organizations and making it more open, exchanging experiences, and accepting other opinions (Blomberg et al., 2017).

Organization in a hotel establishment includes: following the Objective Management System, Human capital, Integration Capability Relative advantage, Staff related innovation, Product innovation, in addition to providing a department for quality and quality control. This leads us to talk about the strategy of Innovation Management creativity.

It makes organizations work to expand existing markets and create new ones, which gives organizations and countries the opportunity to invest in new sectors that were not entered by previous organizations, contribute to achieving social prosperity and the well-being of members of the innovative community. Among the things that help in innovation processes is knowledge, as knowledge has a great role 
and a clear importance on the efficiency and effectiveness of business organizations activities. The study of (Su et al., 2015) emphasizes the importance of knowledge, the results showed that there is a close relationship between knowledge management and innovation, that knowledge management contributes to achieving innovation for organizations through its impact on different dimensions such as individuals, processes and products. Among the things that increased the innovation is the quality processes used and confirmed by a study by (Xu et al., 2018). Quality management applications affect product innovation, process innovation, and management innovation.

There is a close relationship between innovation and excellence, and there are recent approaches to innovation that are always linked to achieving the system of excellence for business organizations. This can be done by developing the skills of creators to en sure their ability to transform their ideas into innovative projects, as they are pillars of excellence in quality, leadership and performance development. Despite the fertility of the terms defining creativity and innovation, controversy still exists around differenc es.

\section{REFERENCES}

Awadi, M. (2015). The role of the Innovation Department in improving the level of innovation and creativity in Arab countries and institutions. Journal of Economic and Financial Studies, University of the Martyr Hama Lakhdar Al-Wadi - College of Economic, Commercial and Management Sciences, 8(3), 242 - 261. https://search.mandumah.com/Record/984901

Al-Sababi, A. (2017). The Effectiveness of Internal Marketing in Hotel Organizations: Study a Sample of Hotels in Chlef State. Journal of Law and Human Sciences, Xian Ashour University in Djelfa, 10, 97-109.

Al-Sumaidaie, M.J., \& Yusef, R.O. (2014). Marketing services, second edition, Dar Al Masirah for Publishing, Distribution and Printing, Amman.

Al Shaire, M. (2014). The Impact of Quality Management Applications on Innovation: An Applied Study on Jordanian Industrial Organizations. Studies Administrative Sciences, The University of Jordan - Deanship of Scientific Research, 41(2), 222 - 239. https://search.mandumah.com/Record/526143

Blomberg, A., Kallio,T., \& Pohjanpaa, H. (2017). Antecedents of organization creativity: drivers, barriers or both. Journal of Innovation Management, 5(1), 78-104.

Bock, G.W., Zmud, R.W., Kim, Y.G., \& Lee, J.N. (2005). Behavioral intention formation in knowledge sharing: Examining the roles of extrinsic motivators, social-psychological forces, and organizational climate. MIS quarterly, 87-111.

Cavagnolli C. (2011). A conceptual framework for innovation: an application to human resource management policies in Australia. Innovation: Management, Policy \& Practice, 13(1), 111-25.

Ciappei, C., \& Simoni, C. (2005). Drivers of new product success in the Italian sport shoe cluster of Montebelluna. Journal of Fashion Marketing and Management, 9 (1), 20-42.

Ciappei, R. (1999). Product Development for the Service Sector: Lessons from Market Leaders. Cambridge, MA, Persueus Books.

Chandrakumara, A., \& Sparrow, P. (2004). Work Orientation as an Element of National Culture and Its Impact on HRM Policy -Practice Design Choices. International Journal of Manpower, 25, (6), 564-589.

Cooper, R. (1999). Product Development for the Service Sector: Lessons from Market Leaders. Cambridge, MA, Persueus Books.

Dzhandzhugazova, E.A., Blinova, E.A., Orlova, L.N., \& Romanova, M.M. (2016). Innovations in hospitality industry. International Journal of Environmental and Science Education, 11(17), 10387-400.

Farah, R., \& Qanur, A. (2017). Knowledge management and its role in achieving innovation among business organizations. Journal of Financial, Accounting and Administrative Studies, 406-4277. https://search.mandumah.com/Record/871558.

García-Morales, V.J., Matías-Reche, F., \& Verdú-Jover, A.J. (2011). Influence of Internal Communication on Technological Proactivity, Organizational Learning, and Organizational Innovation in the Pharmaceutical Sector. Journal of Communication, 61(1), 150-177. https://doi-org.sdl.idm.oclc.org/ $10.1111 / \mathrm{j} .1460-2466.2010 .01530 . \mathrm{x}$

Gottfredson, M., \& Aspinall, K. (2005). Innovation versus complexity: What is too much of good thing? Harvard Business Review, (11), 62-71.

Griffin, A. (1997). PDMA research on new product development practices: Updating trends and benchmarking best practices. Journal of Product Innovation Management, 14(6), 429-458.

Griffin, A., \& Page, A.L. (1993). An interim report on measuring product development success and failure. Journal of Product Innovation Management,10 (3), 291-308.

Griffin, A., \& Page, A.L. (1996). PDMA success measurement project: Recommended measures for product development success and failure. Journal of Product Innovation Management, 13(2), 478-496. Hair, J., Anderson, R., Tatham, R., \& Black, W. (1998). Multivariate data analysis (5 ${ }^{\text {th }}$ ed.). Upper Saddle River, NJ, Prentice Hall.

Grissemann, U., Plank, A., \& Brunner-Sperdin, A. (2013). Enhancing business performance of hotels: the role of innovation and customer orientation, International Journal of Hospitality Management, 33, 347-56.

Guttentag, D.A., \& Smith, S.L. (2017). Assessing Airbnb as a disruptive innovation relative to hotels: Substitution and comparative performance expectations. International Journal of Hospitality Management, 64, 1-10. https://doi:10.1016/j.ijhm.2017.02.003

Hon, A.H. (2011). Enhancing employee creativity in the Chinese context: The mediating role of employee self-concordance. International Journal of Hospitality Management, 30(2), 375-384. https://doi-org.sdl.idm.oclc.org/10.1016/j.ijhm.2010.06.0

Harrington, R.J. (2004). The culinary innovation process: A barrier to imitation. Journal of Foodservice Business Research, 7(3), 35-57.

Hartline, M.D., Maxham J.G., \& McKee, D.O. (2000). Corridors of influence in the dissemination of customer-oriented strategy to customer contact employees. Journal of Marketing, 64(2), 35-50.

Jahmani, A., Bourini, I., \& Jawabreh, O.A. (2020). The Relationship Between Service Quality, Client Satisfaction, Perceived Value and Client Loyalty: A Case Study of Fly Emirates. Cuadernos De Turismo, (45), 219-238. http://dx.doi.org/10.6018/turismo.45.426101

Jawabreh, O., Masa'deh, R., Mahmoud, R., \& Hamasha, S.A. (2020a). Factors Influencing the Employees Service Performances in Hospitality Industry Case Study Aqba Five Stars Hotel. GeoJournal of Tourism and Geosites, 29(2), 649-661. https://doi.org/10.30892/gtg.29221-496

Jawabreh, O., Jahmani, A,. Khaleefah,Q., Alshatnawi, E., \& Abdelrazaqe, H. (2020b). Customer Expectation in Five Star Hotels in Aqaba Special Economic Zone Authority (ASEZA). International Journal of Innovation, Creativity and Change, 11(4).

Jawabreh, O. (2017). An exploratory study of the motives of Jordanian out bound tourism and its impact on the development of tourism in Jordan. International Journal of Applied Business and Economic Research, 15(19 Part-II), 443-467.

Johne, A., \& Storey, C. (1998). New service development: A review of literature and annotated bibliography. European Journal of Marketing, 32(3/4), 184-251.

Jones, P. (1996). Managing hospitality innovation. Cornell Hotel and Restaurant Administration Quarterly, 37(5), 86-95.

Karniouchina, E., Victorino, L., \& Verma, R. (2006). Product and service innovation: Ideas for future cross-disciplinary research. Journal of Product Innovation Management, 23(3), 274-280.

Kotler, P., \& Armstrong, G. (2004). Principles of Marketing. 10th edition, Englewood Cliffs, NJ, Prentice-Hall Inc.

Kotler, P., Bowen, J., \& Makens, J. (2006). Marketing for hospitality and tourism. Upper Saddle River, NJ, Prentice Hall.

Laurie, D., Doz, Y., \& Sheer, C. (2006). Creating new growth platforms. Harvard Business Review, 84(5), 80-90.

Laugen, B.T., Acur, N., Boer, H., \& Frick, J. (2005). Best manufacturing practices: What do the best-performing companies do?, International Journal of Operations Production, Management, 25 (2),131-150.

Leiponen, A. (2006). Managing knowledge for innovation: The case of business-tobusiness services. Journal of Product Innovation Management, 23(3), 238-258.

Lee, J. \& Jang, Y.J. (2016). The effect of comparative advantage of host country's industry on multinationals' M\&A vs greenfield FDI decisions. Journal of Korea Trade, 20(3), 229-258. https://ezlibrary.ju.edu.jo:2057/10.1108/JKT-09-2016-013

Mahdavi, M., \& Pirzad, A. ( 2017). Study on Effect of Intellectual Capital on Knowledge Sharing (Case Study: Department of Housing Foundation Fars Province). International Business Management, 11, 814-820. https://doi.org/10.36478/ibm.2017.814.820 
Masadeh, R., Alananzeh, O., Jawabreh, O., Alhalabi, R., Syam, H., \& Keswani, F. (2019). The association among employee's communication skills, image formation and tourist behaviour: perceptions of hospitality management students in Jordan. International Journal of Culture, Tourism and Hospitality Research, 13(3), 257-272. https://doi.org/10.1108/ijcthr-02-2018-0028

McDonough, E. (2000). Investigation of factors contributing to the success of crossfunctional teams. Journal of Product Innovation Management, 17 (2), 221-235.

Montoya-Weiss, M.M., \& Calantone, R. (1994). Determinants of new product performance: A review and meta-analysis. Journal of Product Innovation Management, 11(5), 397-417.

Ofondu, M.M. (2018). Assessing the Effectiveness of Innovation Management in the Hospitality Industry: A Study of Selected Hotels in South-East, Nigeria. Business Management and Strategy, 9(1), 196. https://doi.org/:10.5296/bms.v9i1.13300

Ottenbacher, M., \& Gnoth, J. (2005). How to develop successful hospitality innovation. Cornell Hotel and Restaurant Administration Quarterly, 46(2), $205-222$.

Ottenbacher, M., Shaw, V., \& Lockwood, A. (2005). An Investigation of the Factors Affecting Innovation Performance in Chain and Independent Hotels. Journal of Quality Assurance in Hospitality \& Tourism, 6(3/4), 113-128. https://doi-org.sdl.idm.oclc.org/10.1300/J162v06n03-07

Ottenbacher, M., Gnoth, J., \& Jones, P. (2006). Identifying determinants of success in development of new high-contact services: Insight from the hospitality industry. International Journal of Service Industry Management, 17(3), 344-363.

Ottenbacher, M., \& Gnoth, J. (2005). How to develop successful hospitality innovation. Cornell Hotels and Restaurant Administration Quarterly, 46(2), 205-222.

Ottenbacher, E.R.G., Gwozdz, W., \& Hvass, K.K. (2018). Exploring the relationship between business model innovation, corporate sustainability, and organizational values within the fashion industry. Journal of Business Ethics, 149(2), 267-284.

Parasuraman, A., Berry, L.L., \& Zeithaml, V.A. (1991). Understanding customer expectations of service. Sloan Management Review, 32(3), 39-48.

Pfeffer, J. (1994). Competitive advantage through people: Unleashing the power of the work force. BostonHarvard Business School Press.

Pikkemaat, B., \& Peters, M. (2005). Towards the measurement of innovation - a pilot study in the small and medium sized hotel industry. Journal of Quality Assurance in Hospitality and Tourism, 6 (3/4),89-112.

Qin, Y., Li, B., \& Yu, L. (2015). Management innovations in a Chinese hotel company: the case of 7 Days Inn. International Journal of Contemporary Hospitality Management, 27(8), 1856-1880. https://ezlibrary.ju.edu.jo:2057/10.1108/IJCHM-02-2014-0080

Rifai, M.A. (2012). Innovation Strategies: The Administration's Path to Root Innovation, Small Business Support and Development Conference. Ain Shams University - Faculty of Commerce and Human Rights Organization, Cairo. Faculty of Commerce, Ain Shams University and the National International Organization for Human Rights, 387 - 404. https://search. mandumah.com/Record/166400

Rogers, E. (1983). Diffusion of innovations. New York, Free Press.

Rodríguez-Victoria, O.E., Puig, F. \& González-Loureiro, M. (2017). Clustering, innovation and hotel competitiveness: evidence from the Colombia destination. International Journal of Contemporary Hospitality Management, 29(11), 2785-2806. https://ezlibrary.ju.edu.jo:2057/10.1108/IJCHM-03-2016-0172

Selden, L., \& MacMillan, I.C. (2006). Manage customer-centric innovation - Systematically. Harvard Business Review, 84(4), $108-116$.

Sethi, R. (2000). New product quality and product development teams. Journal of Marketing, 64(1), 1-14.

Shin, H., Perdue, R.R., \& Kang, J. (2019). Front desk technology innovation in hotels: A managerial perspective. Tourism Management, 74, 310-318. https://doi.org/10.1016/j.tourman.2019.04.004

Song, M., \& Parry, M. (1997). A cross-national comparative study of new product development processes: Japan and the United States. Journal of Marketing, 61(1), 1-18.

Soosary, C., \& Hyland, P.W. (2004). Driving innovation in logistics: case studies in distribution centres. Creativity and Innovation Management, $13(1)$, 41-51.

Storey, C., \& Easingwood, C.J. (1998). The augmented service offering: A conceptualization and study of its impact on new service success. Journal of Product Innovation Management, 15(4), 335-351.

Storey, C., \& Easingwood, C.J. (1999). Types of new service performance: Evidence from the consumer financial services sector. Journal of Business Research, 46(2), 193-203.

Su, S., Baird, K., \& Schoch, H. (2015). The moderating effect of organisational life cycle stages on the association between the interactive and diagnostic approaches to using controls with organisational performance. Management Accounting Research, 26, 40-53. https://doi.org/10.1016/j.mar.2014.09.001

Van Duivenboden, H., \& Thaens, M. (2008). ICT-driven innovation and the culture of public administration: a contradiction in terms?. Information polity, 13(3, 4), 213-232.

Wang, T.C., Tang, T.W., \& Cheng, J.S. (2018). Art-oriented model of hotel service innovation. International Journal of Contemporary Hospitality Management, 30(1), 160-177.

Wijethilake, C., Munir, R., \& Appuhami, R. (2018). Environmental innovation strategy and organizational performance: enabling and controlling uses of management control systems. Journal of Business Ethics, 151(4), 1139-1160.

$\mathrm{Xu}, \mathrm{H}$., Liu, Y., \& Lyu, X. (2018). Customer value co-creation and new service evaluation: the moderating role of outcome quality. International Journal of Contemporary Hospitality Management, 30(4), 2020-2036.

Zhou, L., Zhao, S., Tian, F., Zhang, X. \& Chen, S. (2018). Visionary leadership and employee creativity in China. International Journal of Manpower, 39(1), 93-105. https://ezlibrary.ju.edu.jo:2057/10.1108/IJM-04-2016-0092

Zubeltu-Jaka, E., Andicoechea-Arondo, L., \& Alvarez Etxeberria, I. (2018). Corporate social responsibility and corporate governance and corporate financial performance: bridging concepts for a more ethical business model. Business Strategy and Development, 1(3), 214-222

Article history: Received: 06.08.2020 Revised: 11.09.2020 Accepted: $30.10 .2020 \quad$ Available online: 19.11 .2020

